\title{
Organisatiekenmerken en het gebruik van digitale platforms
}

\author{
Ferry Koster ${ }^{*}$
}

De laatste bijdrage van het Dossier richt zich op de vraag welke organisatiekenmerken kunnen verklaren waarom organisaties gebruikmaken van digitale platforms. Waar bestaand onderzoek verklaringen vooral zoekt in kenmerken van de technologie zelf, gaat in dit onderzoek de aandacht uit naar drie meer algemene organisatiekenmerken, te weten (1) ervaringen met technologie; (2) opvattingen over technologie; en (3) aandacht binnen arbeidsorganisaties voor menselijk kapitaal. Er wordt onderscheid gemaakt tussen twee typen online platforms, namelijk: platforms voor het aanbieden van producten en diensten, en platforms voor het samenwerken met andere organisaties. Aan de hand van data over 678 organisaties in Nederland analyseren we of de drie organisatiekenmerken bijdragen aan het gebruik van digitale platforms. Terwijl ervaringen en opvattingen een verklaring bieden voor beide typen platforms, draagt aandacht voor menselijk kapitaal alleen bij aan het gebruik van platforms voor het samenwerken met andere organisaties.

\section{Inleiding}

Digitale platforms zijn niet meer weg te denken uit het economische verkeer (Zysman \& Kenney, 2017). Hoewel digitale platforms al een tijdje in omloop zijn (Evans, Hagiu \& Schmalensee, 2006), heeft het aantal studies hiernaar recent een vlucht genomen (Kenney \& Zysman, 2016). Daarbij gaat doorgaans veel aandacht uit naar bekende platformorganisaties, zoals Facebook, Google en Salesforce. Voor een groot deel richt het bestaande onderzoek zich op kenmerken van die platformorganisaties, bijvoorbeeld door te bestuderen wat die organisaties onderscheidt van andere organisaties, wat hun succes verklaart en welke consequenties zij bijvoorbeeld hebben voor de groei van de economie (Thomas, Autio \& Gann, 2014; De Reuver, Sørensen \& Basole, 2017).

Het ontstaan en bestaan van platformorganisaties is echter slechts één kant van de platformeconomie. De andere kant is het gebruik dat bestaande organisaties maken van de technologie die platformorganisaties ontwikkelen en aanbieden, bijvoorbeeld door (meer) in contact te treden met klanten, afnemers en partners. Veel organisaties onderschrijven dat de mogelijkheden tot samenwerking en het uitwisselen van kennis een belangrijke, zo niet de belangrijkste, meerwaarde is die digitale platforms bieden (zie bijvoorbeeld IBM, 2014; Tan \& Kom, 2015). Digitale platforms vergemakkelijken contacten met externe partijen omdat gegevens

* $\quad$ Ferry Koster is bijzonder hoogleraar Innovatieve samenwerking bij TIAS en hij is werkzaam als universitair hoofddocent bij de Erasmus Universiteit Rotterdam. 
centraal opgeslagen kunnen worden, er online met elkaar overlegd kan worden, documenten gelijktijdig bewerkt kunnen worden en projecten gezamenlijk gemanaged kunnen worden (Miller, 2008; Payton, 2010; Marston e.a., 2011; Tan \& Kom, 2015). Gebruikers hebben toegang tot gedeelde bronnen (netwerken, servers, applicaties en diensten) die doorgaans flexibel zijn omdat zij aangepast kunnen worden aan hun individuele wensen (Mell \& Grance, 2011). De platformeconomie beperkt zich met andere woorden niet tot techbedrijven. Ook 'traditionele' organisaties maken er in toenemende mate deel van uit. Die organisaties gaan echter niet als vanzelf over tot het digitaliseren van contacten met anderen. In de praktijk blijken zich de nodige obstakels voor te doen, bijvoorbeeld omdat naast voordelen als lagere kosten en meer flexibiliteit de nodige risico's bestaan, zoals veiligheid van data en betrouwbaarheid van het systeem (Brender \& Markov, 2013).

Onderzoek naar het gebruik van nieuwe technologie houdt zich voor een groot deel bezig met de vraag onder welke omstandigheden organisaties overgaan tot het gebruik ervan. De bredere theoretische vraag die in deze literatuur centraal staat, is onder welke omstandigheden organisaties bepaalde technologieën adopteren. De algemene theorieën die in het licht daarvan ontwikkeld zijn, worden vervolgens toegepast op een specifiek onderwerp, zoals robotisering (Dekker, 2016), nieuwe vormen van informatietechnologie (Struik e.a., 2016) of de cloud (Guiterrez, Boukrami \& Lumsden, 2015). Voor het verklaren ervan worden algemene theorieën over adoptie van technologie vertaald naar die onderwerpen. In de literatuur zijn in de basis drie centrale verklaringsmodellen te vinden, te weten het Technology Acceptance Model (TAM; Davis, 1986), het Diffusion of Innovation-model (DOI; Rogers, 2003 [1962]) en het Technology, Organization and Environment-model (TOE; Tornatzky \& Fleischer, 1990). Elk van deze modellen richt zich op een specifiek onderdeel van de beslissing die managers nemen bij de technologie die zij toepassen in hun organisatie. Een aantal recente onderzoeken probeert deze verschillende modellen dan ook te integreren (zie bijvoorbeeld Gangwar, Date \& Ramswamy, 2015; Guiterrez e.a., 2015). Daarvan is TAM het meest individueel georiënteerde model, omdat het toegevoegde waarde en gebruiksgemak van de gebruiker centraal stelt, het DOI-model verklaart adoptie van nieuwe technologie aan de hand van de voordelen die het oplevert en in hoeverre het aansluit bij de rest van de organisatie, en in het TOE-model wordt de verklaring gezocht in de context waarin de technologie wordt toegepast. Opvallend is dat in alle drie de modellen de verklaringen vrij dicht tegen de gebruikte technologie aan zit. Het gaat dus bijvoorbeeld om de vraag naar de beschikbaarheid van een specifieke technologie (zoals cloud computing), de toegevoegde waarde ervan, de complexiteit ervan en eventuele cursussen die het personeel gevolgd heeft die bijdragen aan het adopteren van een specifieke vorm van technologie.

De vraag die daarmee niet wordt beantwoord, is of het zo is dat meer algemene organisatiekenmerken eveneens bijdragen aan het adopteren van technologie. Kortom, het is wel bekend dat organisaties een sterkere neiging hebben over te gaan tot het gebruik van een nieuwe technologie zoals cloud computing als de kosten opwegen tegen de baten, maar we hebben minder zicht op meer algemene 
(achterliggende of onderliggende) factoren die daaraan bijdragen. Waar bestaand onderzoek zich in sterke mate richt op kenmerken van de technologie of de mate waarin het aansluit bij de rest van de organisatie, richt deze studie zich op de aanwezigheid van voorwaarden binnen de arbeidsorganisatie die de introductie van nieuwe technologieën kunnen vergemakkelijken. Deze kenmerken zijn meer algemeen van aard, aangezien zij niet direct gerelateerd zijn aan de technologie, maar een indruk geven van het vermogen van organisaties om nieuwe technologieën te introduceren. Daarbij concentreert deze studie zich op de volgende drie organisatiekenmerken: (1) ervaringen met technologie; (2) opvattingen over technologie; en (3) aandacht voor menselijk kapitaal. Van elk van deze kenmerken valt te verwachten dat zij de onzekerheid rond het invoeren van een nieuwe technologie als digitale platforms verlagen. De vraag is daarmee of positieve ervaringen, positieve verwachtingen en voldoende menselijk kapitaal verklaren waarom organisaties gebruikmaken van digitale platforms. Daarmee tracht dit onderzoek tot aanvullende verklaringen voor technologie-adoptie te komen.

Voor beantwoording van de centrale onderzoeksvraag sluiten we aan bij voornoemde modellen. Terwijl eerdere studies vooral het type technologie centraal stellen, richt dit onderzoek zich juist op de vraag met welk doel technologie wordt ingezet. Hier onderscheiden wij twee verschillende vormen, namelijk (a) het gebruik van digitale platforms voor het aanbieden van producten en diensten, en (b) het gebruik van digitale platforms voor samenwerking met andere organisaties. De specifieke aard van de technologie wordt in dit onderzoek verder buiten beschouwing gelaten. In plaats daarvan gaat de interesse uit naar het doeleinde waarvoor die technologie wordt ingezet (zoals contact met afnemers en contact met partners). Door hier onderscheid in aan te brengen is het mogelijk te onderzoeken of het uitmaakt waarvoor de digitale platforms worden toegepast, in termen van voorwaarden die het gebruik ervan stimuleren en faciliteren. Aan de hand van data over 678 Nederlandse organisaties toetsen we een aantal veronderstellingen.

\section{Theoretisch kader}

Digitale platforms waarmee organisaties contacten kunnen onderhouden met afnemers en partners impliceren dat de organisatie afhankelijk(er) is van haar externe omgeving. $\mathrm{Nu}$ is het goed voorstelbaar dat veel organisaties een directe relatie hebben met dergelijke partijen (in Nederland geeft rond de 60 procent van de organisaties aan samen te werken met externe partijen; Koster, 2015), dus het hoeft niet zozeer te betekenen dat er geheel nieuwe relaties ontstaan. Het gaat erom dat die relaties op digitale wijze worden vormgeven. Uiteraard kan dit wel met zich brengen dat er andere relaties ontstaan, bijvoorbeeld omdat het gemakkelijker wordt om klantcontacten uit te breiden of om met meer organisaties samen te gaan werken. Dergelijke voordelen van digitale platforms worden in de literatuur doorgaans genoemd en benadrukt. Daar staat echter tegenover dat zowel het toepassen van nieuwe technologie als het samenwerken met andere organisaties risico's met zich kan brengen. Naast de voordelen van nieuwe tech- 
nologie wordt daarnaast benadrukt dat implementatie gekenmerkt wordt door een grote mate van uitkomstonzekerheid (Lambooij \& Koster, 2016); vooraf is het eenvoudigweg niet goed in te schatten of de technologie zal werken zoals verwacht en zal bijdragen aan het functioneren van de organisatie als geheel. Wat het samenwerken met andere organisaties betreft, zijn de belangrijkste opbrengsten het delen van hulpbronnen, het spreiden van risico's en het uitwisselen van kennis. Daartegenover staan risico's als het verlies van controle, opportunisme van de andere partij en moeizame informatie-uitwisseling (Pouwels \& Koster, 2017). In het algemeen mogen we verwachten dat eerder wordt overgegaan op het gebruik van nieuwe technologie zodra de bijbehorende risico's zo veel mogelijk gereduceerd worden. De volgende vraag is of het mogelijk is kenmerken van organisaties te selecteren die het waarschijnlijk maken dat zij hiertoe beter in staat zijn. Op basis van de eerder besproken modellen - het TAM, het DOI- en TOEmodel - aangevuld met inzichten uit de organisatieliteratuur is het mogelijk om een drietal factoren op voorhand te benoemen. Wat de organisatieliteratuur betreft, wordt daarbij aangesloten bij verschillende tradities, te weten die over organisatieleren, toekomstverwachtingen en menselijk kapitaal (March, 1991; Subramaniam \& Youndt, 2005; Vecchiato \& Roveda, 2010). Die werken we hieronder verder uit.

\section{Ervaringen met technologie: innovatiegerichtheid}

Het eerste uitgangspunt is dat organisaties gaandeweg lessen kunnen trekken uit eerdere ervaringen met het introduceren van nieuwe technologie in de organisatie. Het introduceren van nieuwe technologie gaat gepaard met onzekerheid, omdat vooraf moeilijk is in te schatten of het zal bijdragen aan de doelstellingen van de organisatie. Organisaties die hier meer ervaring mee hebben, leren hoe zij daar op een succesvolle manier mee om kunnen gaan en ontwikkelen daarvoor een arsenaal aan standaardreacties en routines (March, 1991). Deels sluit het idee van leren en het ontwikkelen van routines aan bij het DOI-model. In dat model wordt een aantal kenmerken van technologie benadrukt, zoals complexiteit en complementariteit. Bij complexiteit gaat het erom hoe ingewikkeld de technologie eigenlijk is, en bij complementariteit gaat het erom in hoeverre de technologie aansluit bij de rest van de organisatie. Organisatieleren en routines kunnen hier als volgt toe bijdragen. Door ervaring op te bouwen zijn organisaties beter in staat die complexiteit te reduceren en tegelijkertijd stelt het hen in staat tot een betere afstemming van organisatieonderdelen te komen. Het idee is hier dat een organisatie niet elke keer opnieuw hoeft te bedenken welke keuzes gemaakt moeten worden, wat de hoeveelheid keuzes reduceert. Door vaker vernieuwingen door te voeren leert een organisatie wat al dan niet werkt en kan daarnaast een betere afstemming met de rest van de organisatie worden bewerkstelligd. Ook hier wordt het aantal keuzeopties verkleind, aangezien niet-succesvolle keuzes op voorhand kunnen worden uitgesloten. Volgens het TAM zijn de verwachte meerwaarde en het gebruiksgemak doorslaggevend voor de keuze van een nieuwe technologie en de bereidheid die te gebruiken. Ook hier valt te verwachten dat als organisaties daar in het verleden succesvoller in zijn geweest, de neiging groter zal zijn een nieuwe technologie te benutten (gesteld dat deze toegevoegde waarde 
zal hebben). Een overkoepelend kenmerk van dergelijke organisaties zal zijn dat zij innovatiever zijn, dat wil zeggen dat zij vaker dan andere organisaties vernieuwingen doorvoeren in hun organisatie, hetzij in termen van nieuwe producten en diensten, maar ook door nieuwe markten aan te boren en processen in de organisatie te verbeteren.

\section{Opvattingen over nieuwe technologie}

In zowel het TAM als het DOI- en TOE-model nemen verwachtingen een centrale plaats in. Die verwachtingen zijn in de modellen direct gekoppeld aan de specifieke technologie waarop het onderzoek betrekking heeft. In het TAM gaat het daarbij om de verwachting dat die technologie toegevoegde waarde heeft, in het DOI-model staan concurrentievoordelen centraal, en in het TOE-model gaat het er ook om hoe het gebruik van die technologie van invloed is op de verhouding met concurrerende organisaties en samenwerkingspartners. Op een meer algemeen niveau spelen verwachtingen van het management van organisaties ten aanzien van nieuwe technologieën hier een rol. Daarbij wordt onderscheid gemaakt tussen twee extreme posities, te weten: technofobie (een grote angst voor nieuwe technologie) en technofilie (een grote liefde voor alles wat met technologie te maken heeft) (Osiceanu, 2015). Nader onderzoek laat zien dat deze psychologische mechanismen te plaatsen zijn in het oorspronkelijke TAM (Brosnan, 1998), namelijk in die zin dat mensen die hoger scoren op technofobie ervan uitgaan dat het gebruik van die nieuwe technologie tot minder toegevoegde waarde leidt dan mensen die daar lager op scoren. Dit heeft vervolgens tot gevolg dat zij die technologie minder snel zullen adopteren. Aangenomen mag worden dat zij die nieuwe technologie als een kans beschouwen, ook eerder zullen overgaan tot gebruik in hun eigen organisatie.

\section{Aandacht voor menselijk kapitaal}

Binnen bestaande modellen van technologieadoptie hebben ondersteunende en faciliterende omstandigheden op het werk een centrale plaats. In het gecombineerde TAM/TOE-model van Gangwar e.a. (2015) valt dit onder de noemer 'organisatiecompetentie', en in een uitgebreide versie van het TAM, zoals dat is uitgewerkt in the unified theory of acceptance and use of technology (Venkatesh e.a., 2003) worden zogenaamde 'faciliterende condities' genoemd. De gedachte achter deze competenties en condities is dat organisaties ervoor zorg dienen te dragen dat er voldoende hulpbronnen aanwezig zijn binnen de organisatie om ervoor te zorgen dat organisaties in staat worden gesteld de nieuwe technologie toe te passen op de werkplek. Het menselijk kapitaal van de organisatie speelt hierin een belangrijke rol, aangezien personeel voldoende geschoold dient te zijn om te kunnen omgaan met nieuwe technologie. Of, andersom gesteld, het is niet waarschijnlijk dat organisaties die niet investeren in de kennis, vaardigheden en competenties van hun personeel in staat zijn potentieel nieuwe technologieën volledig te benutten. Zodra te weinig menselijk kapitaal voorhanden is om met de nieuwe technologie te kunnen werken, wordt het ook minder waarschijnlijk dat een organisatie die technologie daadwerkelijk zal adopteren. 
Samengevat leidt het voorgaande tot een drietal hypothesen over de relatie tussen organisatiekenmerken en het gebruik van digitale platforms, te weten: het gebruik van digitale platforms is hoger naarmate organisaties innovatiever zijn (hypothese 1), naarmate nieuwe technologie meer als kans wordt gezien (hypothese 2), en naarmate organisaties meer gericht zijn op het ontwikkelen van hun personeel (hypothese 3).

\section{Onderzoeksaanpak}

De analyses zijn gebaseerd op data die zijn verzameld in het kader van het onderzoeksproject Innovatief Personeelsbeleid (zie Koster e.a., 2017). In het kader van dat project is een survey gehouden onder een steekproef van Nederlandse organisaties in de private sector. De data zijn verzameld door Kantar Public. Daarvoor hebben zij gebruikgemaakt van de NIPObase Business. Dit panel bevat 15.000 vertegenwoordigers van organisaties in Nederland (zie www.nipo.nl/panel/ businesspanel/). Deze vertegenwoordigers vormen een afspiegeling van Nederlandse organisaties wat betreft de sectoren waarin zij opereren en hun organisatieomvang. Uit dit panel is een random steekproef getrokken van 3.000 bedrijven, waarvan er 752 zijn ondervraagd. Omdat de respondenten niet alle vragen hebben beantwoord die relevant zijn voor dit onderzoek, kon een aantal organisaties niet worden meegenomen in de analyses. In het huidige onderzoek zijn de data van 678 (23 procent van de steekproef) geanalyseerd. Uit tabel 1 is af te lezen dat de organisaties die zijn meegenomen in de analyses opereren in verschillende sectoren en verschillen naar organisatieomvang. De relatieve omvang van de groepen komt overeen met de feitelijke verdeling van organisaties in de Nederlandse economie. In de vragenlijst zijn vragen gesteld over diverse aspecten van organisaties, zoals ontwikkelingen waarmee die organisaties te maken krijgen en hun personeelsbeleid. Daarnaast is gevraagd naar samenwerkingsrelaties en het gebruik van digitale platforms.

\section{Het gebruik van digitale platforms}

In welke mate organisaties gebruikmaken van digitale platforms is op twee manieren gemeten, namelijk: (1) of zij gebruikmaken van online platforms voor het aanbieden van producten en diensten (de variabele 'Online platforms - producten en diensten'), en (2) of zij gebruikmaken van online platforms voor het samenwerken met andere organisaties (de variabele 'Online platforms - samenwerking'). Beide vragen zijn gemeten op een vijfpuntschaal, lopend van helemaal niet van toepassing tot helemaal van toepassing.

\section{Organisatiekenmerken}

Innovatiegerichtheid van de organisaties is gemeten aan de hand van een schaal. In de vragenlijst is aan respondenten gevraagd om aan te geven in hoeverre zij in het afgelopen jaar de volgende vernieuwingen hebben doorgevoerd: het lanceren van producten of diensten die nieuw zijn voor de markt; het lanceren van producten of diensten die al op de markt waren, maar de organisatie nog niet aanbood; het 
introduceren van nieuwe processen (manieren van produceren); het ontwikkelen/ invoeren van nieuwe manieren van marketing; en het sterk verbeteren van producten of diensten die de organisatie al bood. Elk van deze items is gemeten op een schaal van helemaal niet van toepassing (1) tot helemaal van toepassing (5). De schaal heeft een Cronbach's alfa van 0,855.

Opvattingen over nieuwe technologie zijn gemeten door respondenten te vragen aan te geven of zij digitalisering als kans zien op een schaal van (1) een sterke bedreiging tot (5) een sterke kans.

Aandacht voor menselijk kapitaal bestaat uit vijf items (gemeten op een vijfpuntschaal van helemaal niet van toepassing naar helemaal van toepassing). Aan de hand van deze items is organisaties gevraagd of er een jaarlijks budget voor ontwikkeling van personeel is, of er training en cursussen worden aangeboden, of er voornamelijk op de werkvloer geleerd wordt, of inwerktijd vereist is en of er regelmatig geïnventariseerd wordt welke vaardigheden en competenties vereist zijn. De schaal heeft een Cronbach's alfa van 0,804.

\section{Controlevariabelen}

Eerder onderzoek laat zien dat een aantal andere organisatiefactoren eveneens van invloed kunnen zijn op het gebruik van nieuwe technologie. Voor een aantal van die factoren controleren we in de analyses. Uit de literatuur blijkt dat het gebruik van digitale platforms gerelateerd is aan organisatieomvang (Gupta, Seetharaman \& Raj, 2013). De variabele 'Aantal medewerkers' is daarom opgenomen in de analyse. Daarnaast is meegenomen tot welke economische sector de organisatie behoort. Dit vormt een algemene controle voor organisatiekenmerken en de omgeving waarin organisaties zich bevinden, zoals centraal staan in het TOEmodel (Guiterrez e.a., 2015). In totaal zijn 12 sectoren onderscheiden (Industrie, Bouwnijverheid, Detailhandel - food, Detailhandel - non-food, Groothandel, Auto en reparatie, Horeca, Transport, opslag en communicatie, Zakelijke dienstverlening, Overige dienstverlening, IT en Financiële instellingen). Ten slotte is gecontroleerd voor het opleidingsniveau van het personeel en de mate waarin binnen de organisatie bedrijfsspecifieke kennis is vereist. Deze variabelen zijn meegenomen om te controleren voor de kennisintensiteit van de organisatie. Dit is een kenmerk dat de adoptie van technologie mogelijk beïnvloedt. De variabelen zijn beide gemeten op een viffpuntschaal (variërend van helemaal niet van toepassing tot helemaal van toepassing). De variabele 'Hooggeschoolden' is gemeten door aan de organisaties te vragen of zij 'veelal hoogopgeleid personeel in dienst' hebben. Bij de variabele 'Bedrijfsspecifieke kennis' konden respondenten aangeven in hoeverre 'bedrijfsspecifieke kennis en vaardigheden van belang zijn voor het uitvoeren van het werk in de organisatie'.

De data zijn geanalyseerd met een OLS-regressieanalyse. Voor beide afhankelijke variabelen ('Gebruik van digitale platforms voor het aanbieden van producten en diensten' en 'Gebruik van digitale platforms voor de samenwerking met andere organisaties') zijn dezelfde modellen opgesteld. Eerst is een model geschat met de controlevariabelen. Vervolgens is een model geschat waarin de verklarende variabelen zijn toegevoegd. 


\section{Resultaten}

Tabel 1 aan het einde van dit artikel geeft een beschrijving van de variabelen die zijn meegenomen in het onderzoek. Dit geeft om te beginnen inzicht in de vraag hoeveel organisaties gebruikmaken van digitale platforms. Hieruit komt naar voren dat digitale platforms iets vaker worden gebruikt voor het aanbieden van producten en diensten $(m=2,65)$ dan voor het samenwerken met andere organisaties $(m=2,26)$. Voor het gebruikmaken van digitale platforms voor het aanbieden van producten en diensten gaat het om 35 procent van de organisaties, en voor het samenwerken met andere organisaties gaat het om 18 procent van de organisaties. Daarnaast blijkt dat het gebruik van beide digitale platforms onderling samenhangt ( $r=0,556$; correlatietabel op aanvraag beschikbaar).

Tabel 2 en 3 aan het einde van dit artikel geven de resultaten van de regressieanalyses weer. Het gebruikmaken van digitale platforms voor het aanbieden van producten en diensten is positief gerelateerd aan de mate van innovativiteit van de organisatie en de mate waarin digitalisering wordt gezien als kans. Er is geen verband met de ontwikkeling van het personeel. De uitkomsten voor het gebruikmaken van digitale platforms rond samenwerking met andere organisaties zijn enigszins anders: naast innovativiteit en een positief beeld ten aanzien van nieuwe technologie is ook aandacht voor het personeel hier positief aan gerelateerd. Daarnaast blijkt dat sectoren hier onderling in verschillen. Deze verschillen blijven bestaan of worden zelfs versterkt als de onderzochte variabelen zijn toegevoegd. Samengenomen zijn twee van deze uitkomsten helemaal in lijn met de vooraf opgestelde hypothesen: het gebruik van online platforms is groter onder organisaties die eerdere ervaringen hebben met nieuwe technologie en dus van oudsher innovatiever zijn, en onder organisaties waarin technologie meer wordt gezien als een kans dan bedreiging. Daarnaast is de hypothese dat aandacht voor menselijk kapitaal daarvoor van belang is, wel ondersteund voor het gebruik van digitale platforms voor het samenwerken met andere organisaties, maar niet voor het gebruik van die platforms voor het aanbieden van producten en diensten. In de volgende sectie wordt nader ingegaan op de implicaties van deze uitkomsten.

\section{Conclusie en discussie}

In dit onderzoek hebben we antwoord gezocht op de vraag onder welke omstandigheden 'traditionele' organisaties overgaan tot het gebruik van digitale platforms. Aansluitend bij bestaande theorievorming over technologieadoptie was de verwachting dat innovatiegerichtheid, opvattingen over nieuwe technologie en aandacht voor het menselijk kapitaal binnen organisaties relevante voorwaarden vormen voor het overgaan tot het gebruik van digitale platforms. Op basis van gegevens over Nederlandse organisaties luidt de conclusie dat het gebruik van digitale platforms groter is naarmate organisaties innovatiever zijn en digitalisering meer als kans zien. Aandacht voor ontwikkeling van het personeel is wel van belang waar het gaat om de keuze digitale platforms te gebruiken om samen te werken met andere organisaties, maar niet voor digitale platforms waarmee pro- 
ducten en diensten worden aangeboden. Deze uitkomst vraagt om nadere reflectie. Dit betekent dat de gerichtheid op nieuwe producten en diensten minder van organisaties vraagt in termen van menselijk kapitaal dan samenwerking met andere organisaties. Op basis van de literatuur over succesvolle samenwerking tussen organisaties (Hughes \& Weiss, 2007; Koster, 2016), valt dit te begrijpen. Dat onderzoek laat zien dat samenwerkingsverbanden van belang zijn en dat het personeel naast technische kwalificaties beschikken over kennis en vaardigheden op het gebied van samenwerking. In dat opzicht onderschrijft deze uitkomst dat samenwerking met andere organisaties om meer vraagt dan alleen die technische vaardigheden. Dat samenwerking met andere organisaties complexer is dan het aanbieden van producten en diensten, wordt ook ondersteund door het verschil in het gebruik van digitale platforms (35 procent versus 18 procent). Uiteraard is dit slechts een suggestie die nader onderzocht dient te worden.

Het onderzoek heeft een aantal theoretische implicaties. De eerste is dat, in aanvulling op eerder onderzoek, niet alleen organisatiespecifieke voorwaarden van belang zijn bij het begrijpen en verklaren van technologieadoptie. Ook algemene organisatiekenmerken blijken een rol te spelen. Organisatieleren, het ontwikkelen van routines, opvattingen over de toekomst en het zorg dragen voor voldoende menselijk kapitaal bieden een bredere verklaring voor organisatieverschillen in het gebruik van technologie. Enerzijds geeft dit aan dat het voor het begrijpen van technologieadoptie van belang is aandacht te hebben voor organisatieprocessen; zowel verleden als toekomst draagt ertoe bij. Door ervaring op te doen met technologie leren organisaties wat wel en niet werkt, wat zich vervolgens kan vertalen in organisatieroutines waardoor het omgaan met technologie een 'normaal' onderdeel wordt van de organisatie. Dit kan vervolgens opvattingen die heersen binnen de organisatie zo beïnvloeden dat technologie eerder een kans is dan een bedreiging. En ten slotte is, vooral bij samenwerking, van belang dat de organisatie over voldoende menselijk kapitaal beschikt (dat door de tijd wordt ontwikkeld, zodat kennis en vaardigheden afgestemd blijven op de rest van de organisatie). Deze uitkomst biedt ook een insteek voor nieuw onderzoek, met daarin de vraag of die organisatiekenmerken ook een verklaring kunnen zijn voor het gebruik van andere vormen van technologie, zoals de huidige studie suggereert. Daarnaast onderschrijft dit onderzoek dat niet alleen individuele opvattingen over technologie een rol spelen bij het gebruik ervan, maar vooral ook de kenmerken van organisaties waar die technologie wordt toegepast van invloed zijn. Daarbij gaat dit onderzoek verder dan het eerdere onderzoek, aangezien de specifieke technologie daarbij altijd centraal staat. Dat wijst erop dat organisaties kunnen beschikken over een vaardigheid op collectief niveau die aangeeft dat een organisatie in staat is nieuwe informatie tot zich te nemen. Een dergelijke vaardigheid is vergelijkbaar met wat het absorptievermogen van organisaties wordt genoemd (de mate waarin organisaties in staat zijn informatie tot zich te nemen) (Zahra \& George, 2002), maar dan toegepast op aspecten als organisatievernieuwing en het introduceren van nieuwe technologie. De huidige studie suggereert dat organisaties deze vaardigheid kunnen hebben. Nader onderzoek naar deze vaardigheid is echter vereist. Op basis van de theoretische veronderstellingen is een onverwachte uitkomst dat aandacht voor de ontwikkeling van personeel wel 
van belang is bij het gebruik van digitale platforms die gericht zijn op het samenwerken met andere organisaties, maar niet bij het gebruik van digitale platforms voor het aanbieden van producten en diensten. Afgaand op de interpretatie dat het reduceren van risico's van belang is voor technologieadoptie, betekent dit dat aan samenwerking meer risico's zijn verbonden dan aan het aanbieden van producten en diensten (en mogelijk zijn de directe opbrengsten groter). In dat opzicht vormt deze uitkomst een nadere bevestiging van inzichten die blijken uit de samenwerkingsliteratuur. Als een organisatie wil samenwerken via digitale platforms, is het van belang dat het personeel voldoende is geschoold en getraind. Ten slotte geeft dit onderzoek meer inzicht in de omvang van de platformeconomie. Duidelijk is dat deze omvang niet moet worden overdreven. Het onderzoek laat zien dat digitale platforms ook gebruikt worden door 'traditionele' organisaties. Tegelijkertijd is duidelijk dat dat nog lang niet voor alle organisaties opgaat. Vanuit beleidsperspectief biedt dit onderzoek een aantal suggesties voor beleid. Ten eerste wordt doorgaans onderkend dat digitalisering voordelen oplevert voor de Nederlandse economie als geheel. Gezien de constatering dat 65 procent van de organisaties geen gebruik maakt van digitale platforms voor het aanbieden van producten en diensten, en 82 procent van de organisaties geen platforms gebruikt om samen te werken met anderen, is hier de nodige winst te behalen. De uitkomsten van deze studie biedt een aantal aanknopingspunten voor beleidsmakers. Zo kan bijvoorbeeld worden overwogen kennis en ervaring te delen tussen organisaties, zodat ervaringen met technologie en opvattingen over nieuwe technologie ook hun weerslag hebben in andere organisaties. Ten tweede, als digitalisering van de economie ook betekent dat deze meer gebaseerd is op samenwerking tussen organisaties, brengt dat met zich dat investeringen in menselijk kapitaal cruciaal zijn. De huidige studie onderschrijft dat aandacht voor menselijk kapitaal bijdraagt aan samenwerking via digitale platforms. Dat betekent vervolgens dat als organisaties terughoudend zijn om op die manier te gaan samenwerken en daarvan worden weerhouden omdat zij niet in staat zijn daar voldoende aandacht aan te besteden, het de vraag is of hier een taak is weggelegd voor collectieve actoren, hetzij de overheid, hetzij verenigingen van werkgevers en werknemers. Zodra die barrières zijn geslecht, kan de volgende stap in de richting van een platformeconomie worden gezet. 
Tabel 1 Beschrijvende resultaten

\begin{tabular}{|c|c|c|c|c|}
\hline & Min/Max & $\begin{array}{l}\text { Gemid- } \\
\text { delde }\end{array}$ & $\begin{array}{c}\text { Standaard- } \\
\text { deviatie }\end{array}$ & Percentage \\
\hline $\begin{array}{l}\text { Online platforms - producten en } \\
\text { diensten }\end{array}$ & $\mathrm{I} / 5$ & 2,65 & 1,26 & \\
\hline Online platforms - samenwerking & $1 / 5$ & 2,26 & $\mathrm{I}, 09$ & \\
\hline Innovativiteit & $1 / 5$ & 2,41 & 0,95 & \\
\hline Digitalisering: kans & $1 / 5$ & 3,61 & 0,76 & \\
\hline Ontwikkeling personeel & $1 / 5$ & 2,73 & 0,96 & \\
\hline \multicolumn{5}{|l|}{ Sector } \\
\hline Industrie & $0 / 1$ & & & $4,7 \%$ \\
\hline Bouwnijverheid & $0 / 1$ & & & $6,6 \%$ \\
\hline Detailhandel - food & $0 / 1$ & & & $3,1 \%$ \\
\hline Detailhandel - non-food & $0 / 1$ & & & $13,2 \%$ \\
\hline Groothandel & $0 / 1$ & & & $7,4 \%$ \\
\hline Auto en reparatie & $0 / 1$ & & & $1,9 \%$ \\
\hline Horeca & $0 / 1$ & & & $3,9 \%$ \\
\hline Transport, opslag en communicatie & $0 / 1$ & & & $3,2 \%$ \\
\hline Zakelijke dienstverlening & $0 / 1$ & & & $35,2 \%$ \\
\hline Overige dienstverlening & $0 / 1$ & & & $10,2 \%$ \\
\hline IT & $0 / 1$ & & & $8,5 \%$ \\
\hline Financiële instellingen & $0 / 1$ & & & $2,1 \%$ \\
\hline Aantal medewerkers & $1 / 5$ & 1,17 & 0,58 & \\
\hline \multicolumn{5}{|l|}{$\begin{array}{l}\text { Aantal medewerkers (per cate- } \\
\text { gorie) }\end{array}$} \\
\hline $1-9$ & $0 / 1$ & & & $89,5 \%$ \\
\hline $10-49$ & $0 / 1$ & & & $6,5 \%$ \\
\hline $50-99$ & $0 / 1$ & & & $1,7 \%$ \\
\hline $100-249$ & $0 / 1$ & & & $0,9 \%$ \\
\hline 250 of meer & $0 / 1$ & & & $0,9 \%$ \\
\hline Hooggeschoolden & $1 / 5$ & 2,93 & $\mathrm{I}, 57$ & \\
\hline Bedrijfsspecifieke kennis & $1 / 5$ & 3,67 & $\mathrm{I}, 35$ & \\
\hline
\end{tabular}

$\mathrm{N}=678$ organisaties

Bron: Dataset Innovatief Personeelsbeleid. 
Ferry Koster

Tabel 2 Regressieanalyse van 'Gebruik digitale platforms voor het aanbieden van producten en diensten'

\begin{tabular}{|c|c|c|c|c|c|}
\hline & b & s.e & b & & s.e. \\
\hline Constante & $1,972 * * *$ & 0,198 & 0,792 & $* * *$ & 0,276 \\
\hline \multicolumn{6}{|l|}{ Sector } \\
\hline Industrie & $-0,305$ & 0,229 & $-0,267$ & & 0,217 \\
\hline Bouwnijverheid & $-0,351$ & 0,207 & $-0,274$ & & 0,196 \\
\hline $\begin{array}{l}\text { Detailhandel - } \\
\text { food }\end{array}$ & 0,237 & 0,285 & 0,154 & & 0,271 \\
\hline $\begin{array}{l}\text { Detailhandel - } \\
\text { non-food }\end{array}$ & 0,293 & 0,161 & 0,362 & & 0,152 \\
\hline Groothandel & 0,085 & 0,186 & $-0,028$ & & 0,176 \\
\hline Auto en reparatie & $-0,338$ & 0,379 & $-0,221$ & & 0,361 \\
\hline Horeca & 0,039 & 0,251 & 0,066 & & 0,237 \\
\hline $\begin{array}{l}\text { Transport, opslag } \\
\text { en communicatie }\end{array}$ & $-0,167$ & 0,301 & 0,009 & & 0,286 \\
\hline $\begin{array}{l}\text { Overige dienst- } \\
\text { verlening }\end{array}$ & $-0,180$ & 0,167 & $-0,180$ & & 0,158 \\
\hline IT & 0,280 & 0,182 & 0,143 & & 0,174 \\
\hline $\begin{array}{l}\text { Financiële instel- } \\
\text { lingen }\end{array}$ & $-0,343$ & 0,337 & $-0,206$ & & 0,319 \\
\hline $\begin{array}{l}\text { Aantal medewer- } \\
\text { kers }\end{array}$ & 0,184 & 0,083 & 0,063 & & 0,081 \\
\hline Hoogopgeleiden & 0,029 & 0,032 & $-0,009$ & & 0,032 \\
\hline $\begin{array}{l}\text { Bedrijfsspecifieke } \\
\text { kennis }\end{array}$ & $0,120 * *$ & 0,038 & 0,024 & & 0,038 \\
\hline Innovativiteit & & & 0,418 & $* * *$ & 0,057 \\
\hline $\begin{array}{l}\text { Digitalisering - } \\
\text { kans }\end{array}$ & & & 0,242 & $* * *$ & 0,062 \\
\hline $\begin{array}{l}\text { Ontwikkeling per- } \\
\text { soneel }\end{array}$ & & & $-0,039$ & & 0,061 \\
\hline$R^{2}$ & 0,032 & $* *$ & & 0,138 & $* * *$ \\
\hline$R^{2}$ verandering & & & & 0,107 & $* * *$ \\
\hline
\end{tabular}

** $\mathrm{p}<0,01$; *** $\mathrm{p}<0,001$.

$N=678$ organisaties.

Bron: Dataset Innovatief Personeelsbeleid. 
Tabel 3 Regressieanalyse van 'Gebruik digitale platforms voor samenwerking met andere organisaties'

\begin{tabular}{|c|c|c|c|c|c|c|}
\hline & b & & s.e & b & & s.e. \\
\hline Constante & 1,883 & $* * *$ & $0,|7|$ & 0,889 & $* * *$ & 0,238 \\
\hline \multicolumn{7}{|l|}{ Sector } \\
\hline Industrie & $-0,493$ & $* *$ & 0,197 & $-0,470$ & $* *$ & 0,187 \\
\hline Bouwnijverheid & $-0,44 \mid$ & $* *$ & 0,178 & $-0,406$ & $* *$ & 0,169 \\
\hline $\begin{array}{l}\text { Detailhandel - } \\
\text { food }\end{array}$ & $-0,702$ & $* *$ & 0,246 & $-0,783$ & $* * *$ & 0,234 \\
\hline $\begin{array}{l}\text { Detailhandel non- } \\
\text { food }\end{array}$ & $-0,308$ & & 0,138 & $-0,252$ & & $0,13 \mid$ \\
\hline Groothandel & $-0,387$ & & 0,160 & $-0,445$ & $* *$ & 0,152 \\
\hline Auto en reparatie & $-0,447$ & & 0,326 & $-0,519$ & & 0,311 \\
\hline Horeca & $-0,232$ & & 0,216 & $-0,213$ & & 0,205 \\
\hline $\begin{array}{l}\text { Transport, opslag } \\
\text { en communicatie }\end{array}$ & $-0,674$ & & 0,259 & $-0,503$ & & 0,247 \\
\hline $\begin{array}{l}\text { Overige dienst- } \\
\text { verlening }\end{array}$ & $-0,302$ & & 0,144 & $-0,283$ & & 0,136 \\
\hline IT & 0,138 & & 0,157 & 0,083 & & 0,150 \\
\hline $\begin{array}{l}\text { Financiële instel- } \\
\text { lingen }\end{array}$ & $-0,125$ & & 0,290 & $-0,019$ & & 0,275 \\
\hline $\begin{array}{l}\text { Aantal medewer- } \\
\text { kers }\end{array}$ & 0,190 & & 0,071 & 0,037 & & 0,070 \\
\hline Hoogopgeleiden & 0,052 & & 0,028 & $-0,009$ & & 0,028 \\
\hline $\begin{array}{l}\text { Bedrijfsspecifieke } \\
\text { kennis }\end{array}$ & 0,067 & & 0,033 & $-0,032$ & & 0,033 \\
\hline Innovativiteit & & & & 0,284 & $* * *$ & 0,049 \\
\hline $\begin{array}{l}\text { Digitalisering - } \\
\text { kans }\end{array}$ & & & & 0,143 & $* *$ & 0,053 \\
\hline $\begin{array}{l}\text { Ontwikkeling per- } \\
\text { soneel }\end{array}$ & & & & 0,178 & $* * *$ & 0,053 \\
\hline$R^{2}$ & & 0,057 & $* * *$ & & 0,154 & $* * *$ \\
\hline$R^{2}$ verandering & & & & & 0,099 & $* * *$ \\
\hline
\end{tabular}

** $\mathrm{p}<0,0$ I; *** $\mathrm{p}<0,00$ I.

$N=678$ organisaties.

Bron: Dataset Innovatief Personeelsbeleid.

\section{Literatuur}

Brender, N., \& Markov, I. (2013). Risk perception and risk management in cloud computing: Results from a case study of Swiss companies. International Journal of Information Management, 33 (5): 726-733.

Brosnan, M.J. (1998). Technophobia. The psychological impact of Information Technology. Londen/New York: Routledge. 
Davis, F.D. (1986). A technology acceptance model for empirically testing new end-user information systems: Theory and results (dissertation). Cambridge, MA: Sloan School of Management, Massachusetts Institute of Technology.

Dekker, F. (2016). Robots en arbeid: Technologisch determinisme revisited? Beleid en Maatschappij, 43 (2): 24-40.

Evans, D.S., Hagiu, A., \& Schmalensee, R. (2006). Invisible engines. How software platforms drive innovation and transform industries. Cambridge/Londen: The MIT Press.

Gangwar, H., Date, H., \& Ramswamy, R. (2015). Understanding determinants of cloud computing adoption using and integrated TAM-TOE model. Journal of Enterprise Information Management, 28 (6): 788-807.

Guiterrez, A., Boukrami, E., \& Lumsden, R. (2015). Technological, organizational, and environmental factors influencing managers' decision to adopt cloud computing in the UK. Journal of Enterprise Information Management, 28 (1): 107-130.

Gupta, P., Seetharaman, A., \& Raj, J.R. (2013). The usage and adoption of cloud computing by small and medium businesses. International Journal of Information Management, 33 (5): 861-874.

Hughes, J., \& Weiss, J. (2007). Simple rules for making alliances work. Harvard Business Review, 85 (11): 122-132.

IBM (2014). Champions of software as a service: How SaaS is fueling powerful competitive advantage. New York: IBM Center for Applied Insights.

Kenney, M., \& Zysman, J. (2016). The rise of the platform economy. Issues in Science and Technology, 32 (3): 61-69.

Korte, M., \& Koster, F. (2016). Gebruik van een online platform. Een overzicht van de internationale literatuur (ICOON Paper 5). Tilburg: ICOON.

Koster, F. (2015). Samenwerking en innovatie in het MKB in Europa en Nederland. Een exploratie op basis van het European Company Survey (ICOON Paper 1). Tilburg: ICOON.

Koster, F. (2016). Zelf doen is optellen, samen doen is vermenigvuldigen. Organisaties, relaties, innovaties (oratie). Tilburg: Tilburg University.

Koster, F., Korte, M., Goorbergh, P. van de, \& Bloem, D. (2017). Vragenlijst 'Innovatief Personeelsbeleid'. Beschrijvende resultaten (ICOON Paper 10). Tilburg: ICOON.

Koster, F., \& Lambooij, M.S. (2018). Managing innovations. A study of the implementation of Electronic Medical Records in Dutch hospitals. International Journal of Innovation and Technology Management, forthcoming.

Lambooij, M.S., \& Koster, F. (2016). How organizational escalation prevention potential affects success of implementation of innovations: Electronic medical records in hospitals. Implementation Science, 11: 75-84.

March, J.G. (1991). Exploration and exploitation in organizational learning. Organization Science, 2 (1): 71-87.

Marston, S., Li, Z., Bandyopadhyay, S., Zhang, J., \& Ghalsasi, A. (2011). Cloud computing. The business perspective. Decision Support Systems, 51 (1): 176-189.

Mell, P., \& Grance, T. (2011). The NIST definition of cloud computing. Special Publication 800-145. National Institute of Standards and Technology.

Miller, M. (2008). Cloud computing: Web-Based applications that change the way you work and collaborate online. Indianapolis, IN: Que Publishing.

Osiceanu, M.E. (2015). Psychological implications of modern technologies: 'technofobia' versus 'technophilia'. Procedia-Social and Behavioral Sciences, 180: 1137-1144.

Payton, S. (2010). Fluffy logic. Financial Management, november: 22-25.

Pouwels, I., \& Koster, F. (2017). Inter-organizational cooperation and organizational innovativeness. A comparative study. International Journal of Innovation Science, 9 (2): 184-204. 
Reuver, M. de, Sørensen, C., \& Basole, R.C. (2017). The digital platform: A research agenda. Journal of Information Technology, 1-12.

Rogers, E. (2003 [1962]). Diffusion of innovations. New York: Free Press.

Struik, M.H.L., Koster, F., Schuit, A.J., Nugteren, R., Veldwijk, J., \& Lambooij, M.S. (2014). The preferences of users of Electronic Medical Records in hospitals: Quantifying the relative importance of barriers and facilitators of an innovation. Implementation Science, 9: 69-79.

Subramaniam, M., \& Youndt, M.A. (2005). The influence of intellectual capital on the types of innovative capabilities. Academy of Management Journal, 48 (3): 450-463.

Tan, X., \& Kom, Y. (2015). User acceptance of SaaS-based collaboration tools: A case of Google Docs. Journal of Enterprise Information Management, 28 (3): 423-442.

Thomas, L.D., Autio, E., \& Gann, D.M. (2014). Architectural leverage: Putting platforms in context The Academy of Management Perspectives, 28 (2): 198-219.

Tornatzky, L.G., \& Fleischer, M. (1990). The processes of technological innovation. Massachusetts: Lexington Books.

Vecchiato, R., \& Roveda, C. (2010). Strategic foresight in corporate organizations: Handling the effect and response uncertainty of technology and social drivers of change. Technological Forecasting and Social Change, 77 (9): 1527-1539.

Venkatesh, V., Morris, M.G., Davis, G.B., \& Davis, F.D. (2003). User acceptance of information technology: Toward a unified view. MIS Quarterly, 27 (3): 425-478.

Zahra, S.A., \& George, G. (2002). Absorptive capacity: A review, reconceptualization, and extension. Academy of Management Review, 27 (2): 185-203.

Zysman, J., \& Kenney, M. (2017). Intelligent tools and digital platforms: Implications for work and employment. Intereconomics, 52 (6): 329-334. 